\title{
Spatial patterns in soil organic matter dynamics are shaped by mycorrhizosphere interactions in a treeline forest
}

\author{
Nina L. Friggens • Thomas J. Aspray • \\ Thomas C. Parker • Jens-Arne Subke • \\ Philip A. Wookey
}

Received: 26 April 2019 / Accepted: 9 December 2019 /Published online: 26 December 2019

(C) The Author(s) 2019

\begin{abstract}
Aims In the Swedish sub-Arctic, mountain birch (Betula pubescens ssp. czerepanovii) forests mediate rapid soil $\mathrm{C}$ cycling relative to adjacent tundra heaths, but little is known about the role of individual trees within forests. Here we investigate the spatial extent over which trees influence soil processes.

Methods We measured respiration, soil C stocks, root and mycorrhizal productivity and fungi:bacteria ratios at fine spatial scales along $3 \mathrm{~m}$ transects extending radially from mountain birch trees in a sub-Arctic ecotone forest. Root and mycorrhizal productivity was quantified using in-growth techniques and fungi:bacteria ratios were determined by qPCR.

Results Neither respiration, nor root and mycorrhizal production, varied along transects. Fungi:bacteria ratios, soil organic $\mathrm{C}$ stocks and standing litter declined with increasing distance from trees.
\end{abstract}

Responsible Editor: Sven Marhan.

Electronic supplementary material The online version of this article (https://doi.org/10.1007/s11104-019-04398-y) contains supplementary material, which is available to authorized users.

N. L. Friggens $(\bowtie) \cdot$ T. C. Parker · J.-A. Subke •

P. A. Wookey

Biological \& Environmental Sciences, School of Natural Sciences, University of Stirling, Stirling FK9 4LA, UK

e-mail: nina.lindstromfriggens1@stir.ac.uk

\section{N. L. Friggens - T. J. Aspray}

Energy, Geoscience, Infrastructure \& Society, Heriot-Watt University, Edinburgh EH14 4AS, UK
Conclusions As $3 \mathrm{~m}$ is half the average size of forest gaps, these findings suggest that forest soil environments are efficiently explored by roots and associated mycorrhizal networks of $B$. pubescens. Individual trees exert influence substantially away from their base, creating more uniform distributions of root, mycorrhizal and bacterial activity than expected. However, overall rates of soil $\mathrm{C}$ accumulation do vary with distance from trees, with potential implications for spatio-temporal soil organic matter dynamics and net ecosystem $\mathrm{C}$ sequestration.

Keywords Carbon · Ectomycorrhiza · Hyphae - qPCR · Respiration $\cdot$ Rhizosphere

\section{Introduction}

Aboveground plant communities and belowground microbial communities, comprised of saprotrophic and mycorrhizal fungi, bacteria and archaea, form intimate and interdependent relationships (Wardle et al. 2004). Ultimately, any changes to aboveground vegetation communities could have cascading belowground effects on microbial communities, carbon (C) sequestration and turnover (Wookey et al. 2009).

The mountain birch (Betula pubescens Ehrh. ssp. czerepanovii (Orlova) Hämet Ahti) forest - tundra treeline ecotone south of Abisko, Sweden, provides a suitable natural system for studying the effect of aboveground vegetation on fundamental soil processes and belowground $\mathrm{C}$ cycling. The mosaic of forest and tundra heath across the landscape offers several vegetation transitions, 
in permafrost-free areas, reducing potential confounding hydrological effects. Previous research at the treeline near Abisko has established that shrub and tree cover have expanded between 1976 and 2009 (Rundqvist et al. 2011), and that there are clear differences in organic C storage between forest and tundra heath soils (Sjögersten and Wookey 2002). Extensive transect work has further shown that the relatively productive mountain birch forest and deciduous shrubs, with higher above-ground C stocks, have significantly less $\mathrm{C}$ and nitrogen $(\mathrm{N})$ stored belowground compared to the relatively less productive adjacent tundra heath (Hartley et al. 2012; Parker et al. 2015). These differences in below-ground $\mathrm{C}$ stocks and rates of soil $\mathrm{C}$ cycling have been linked to differences in associated belowground mycorrhizal communities between forest and tundra (Parker et al. 2015).

Previous work has focussed on differences in vegetation at the landscape scale, but little is known about the zone of influence of individual trees within treeline forests. Characterising the spatial complexity of soil processes (or lack thereof) in these forests is critical to understanding how soil $\mathrm{C}$ cycling may change with potential forest expansion. In a recent study, Parker et al. (2016) observed that respiration was higher at the base of mountain birch trees compared to $150 \mathrm{~cm}$ away, indicating 'hot-spots' of soil activity close to trees. However, their work lacks further information on possible variation in key soil processes, such as respiration and rhizosphere productivity at finer scales, as well as at greater distances from tree bases. As contrasting vegetation types, and individual birch trees, affect key soil processes (Hartley et al. 2012; Parker et al. 2016), we sought to investigate to what extent individual trees, and their associated root and ectomycorrhizal networks, influence surrounding soil $\mathrm{C}$ cycling. We also sought to determine how far these networks extend and, in addition, we deployed indirect techniques to identify any spatial shifts in the balance between autotrophic and heterotrophic soil $\mathrm{CO}_{2}$ efflux (Subke et al. 2006; Subke and Bahn 2010). Quantifying and understanding fine-scale variation in soil processes is particularly relevant in the mesic ecotone mountain birch forests, as many of these are open in structure with large spacing between trees. This sparse density forest is also common for many arctic treelines across North America and Eurasia (Kullman and Öberg 2009; Payette and Lavoie 1994).

Given this ecological context there are two, potentially mutually exclusive, possibilities regarding spatial variation in the mycorrhizosphere within the forest. (i) If the influence of trees is limited in range, then there may be pockets within forests that function more similarly to tundra heath in terms of their soil processes, with lower respiration, high soil $\mathrm{C}$ stocks and ericoid fungal dominance (Cornelissen et al. 2001; Read and Perez-Moreno 2003). Alternatively, (ii) if the influence of trees and their associated mycorrhizosphere extends beyond the mean maximum distance between trees, there may be contiguous, or overlapping, networks of ectomycorrhizas exploring and exploiting resources throughout the forest floor. This could indicate the presence of a so called wood-wide-web (Beiler et al. 2010; Simard and Durall 2004; Wiemken and Boller 2002) and the potential for common mycelial networks (CMNs) where mycorrhizas associate with multiple plants, and vice versa (Hazard and Johnson 2018; Simard et al. 2012).

Understanding the coupling between plant and microbial communities in the Arctic, and the consequences for fundamental soil processes, is particularly important due to the large amounts of $\mathrm{C}$ stored in high latitude soils (Kuhry et al. 2013; Ping et al. 2008), as well as the substantial allocation of plant biomass below-ground (Iversen et al. 2015). Much of this $\mathrm{C}$ is potentially vulnerable to be released to the atmosphere, if temperatures rise, through its metabolism by soil organisms, constituting a potential positive feedback to climate forcing and the acceleration of climate change (Karhu et al. 2014; Luo 2007). The direct interface between plants and soil is the rhizosphere and the maintenance of symbiotic relationships with mycorrhizal fungi which explore the soil for water and nutrients and receive plant photosynthates (Anderson and Cairney 2007; Smith and Read 2008). In the sub-Arctic, the majority of mycorrhizal associations are those of ericaceous sub-shrubs with ericoid mycorrhizas (ERM), and betulaceae (both tree and dwarf birch) with ectomycorrhizas (ECM) (Cornelissen et al. 2001; Read and Perez-Moreno 2003).

The effects of microorganisms and mycorrhizal fungi on ecosystem function and soil C-cycling depend on the growth form and morphotype of individuals in a microbial community (Clemmensen et al. 2015; Cornelissen et al. 2001). These can vary significantly depending on the soil environment and the above-ground plant communities (Grayston and Prescott 2005; Hazard and Johnson 2018). One example is of ericaceous ERM dominated systems capable of significant $\mathrm{C}$ sequestration in melanised hyphal biomass vs boreal ECM dominated systems with more rapid biomass turnover and 
low C sequestration (Clemmensen et al. 2013, 2015). Another example is where soils below ericaceous dwarf shrubs are dominated by fungi, while those below herbaceous vegetation or temperate woodlands are dominated by bacteria (Högberg et al. 2007; Mitchell et al. 2010). This is thought to be related to differences in the quantity and quality of above- and below-ground litter and root exudates, $\mathrm{C}: \mathrm{N}$ ratios in the soil (Fierer et al. 2009) and soil pH (Mitchell et al. 2010). As fungi have higher $\mathrm{C}$ assimilation efficiency (Zhang et al. 2005), and higher recalcitrance of necromass, than bacteria (Six et al. 2006; Strickland and Rousk 2010), fungal dominated soils sequester more $\mathrm{C}$ and have lower respiration rates than bacterial dominated soil (Averill and Hawkes 2016; Clemmensen et al. 2013, 2015). Understanding the link between vegetation, soils, and the ecological processes they mediate is key to understanding soil C sequestration and turnover at local and landscape scales.

Given the strong influence of mountain birch trees on soil processes around them, we hypothesise the following:

1) Production of fine roots and ectomycorrhizal hyphae declines significantly at increasing distances from tree bases, reflected in declining contributions of autotrophic inputs towards total respiration.

2) Respiration rates show corresponding patterns of decline with increasing distance from tree bases.

3) The ratio of soil fungi:bacteria increases with distance away from tree bases, creating conditions similar to more open heath.

4) The patterns of soil organic carbon stocks will reflect the relative consequences of (a) declining litter deposition, and (b) declining mycorrhizosphere activity, with increasing distances from trees. All other factors remaining equal, the former would tend to contribute to higher $\mathrm{C}$ stocks closer to trees (denoted Hypothesis 4a), while the latter would tend to result in slower turnover of soil C, and higher C stocks, further away from trees (Hypothesis $4 b$ ).

\section{Materials and methods}

Site descriptions

All studied trees were selected within a permafrost-free area (approx. $1 \mathrm{~km}^{2}$ ) in the sub-Arctic treeline ecotone at Nissunsnuohkki, south of Abisko, Sweden (ca. $68^{\circ} 18^{\prime}$
56.2”N $\left.18^{\circ} 49^{\prime} 18.2^{\prime \prime} \mathrm{E}\right), \sim 600 \mathrm{~m}$ asl. The treeline forest comprises mountain birch (Betula pubescens ssp. czerepanovii) and has an open canopy structure with an ericaceous understorey consisting of Vaccinium vitis-idaea, V. myrtillus and Empetrum nigrum ssp. hermaphroditum. In this area the Betula pubescens above-ground biomass was estimated to be $0.066 \pm$ $0.036 \mathrm{~kg} \mathrm{~m}^{-2}$ (mean $\pm \mathrm{SD}$ ) and LAI estimated to be $0.17 \pm 0.11 \mathrm{~m}^{2} \mathrm{~m}^{-2}$ (Dahlberg et al. 2004).

Forest soils are 'microspodosols' with a thin O horizon $(<5 \mathrm{~cm})$ underlain by glacial till on a bedrock typically of hard-shale (Sjögersten and Wookey 2002); Soil $\mathrm{pH}$ in the organic horizon is $4.3 \pm 0.1$ (Parker et al. 2015).

Gradients in relation to distance from single birch trees

\section{Tree selection and transect set-up}

Three blocks of 3 individual trees $(n=9)$ were selected for study (Fig. 1). The blocks were within a $500 \mathrm{~m}$ radius area and at least $150 \mathrm{~m}$ apart. Mountain birch trees of varying size and number of polycormic stems were selected, all located in open forest areas with $\geq 6 \mathrm{~m}$ to any neighbouring trees in the direction of the transect. Care was taken to select various topographical aspects in order to account for variation of influencing factors such as water or snow accumulation. Crown width of all trees was measured in the N-S and E-W orientation and averaged (Supp. Table 2).

Transects were set up in a straight line from the base of each selected tree with measurement locations at 25, 50, $75,100,200$ and $300 \mathrm{~cm}$ from the tree base. Directions of transects were intentionally varied such that each block had transects of differing compass direction to account for shading, prevailing winds or snow drifting, and to allow transects to radiate into open forest gaps.

Digital photographs of each respiration collar were taken from directly above. Image analysis software ImageJ2 (Rueden et al. 2017) was used to determine the percentage vegetation cover of Vaccinium vitisidaea, Empetrum nigrum and cryptogams in collars.

\section{Soil and understorey $C$ fluxes}

At each point along the transects, PVC collars of $15 \mathrm{~cm}$ diameter and $6 \mathrm{~cm}$ height were secured to the soil surface with the centre of the PVC ring corresponding to a given distance. Non-setting putty (Plumber's 
Mait®, Bostik Ltd., Stafford, UK) was used to secure and seal the PVC collars to the soil in order to minimise disturbance of the soil and prevent severing of any roots or fungal hyphae. The forest floor vegetation was parted to allow placement of each collar resulting in vegetation inside and outside the collar (Table 1).

An EGM-4 infrared gas analyser with a darkened CPY-3 chamber (PP Systems International, Amesbury, MA, USA) was used to measure respiration. Respiration in this study is defined as the sum of microbial, root and shoot (including cryptogam) respiration within the chamber, and therefore represents forest soil and understorey respiration. Plants were not initially removed from collars in order to minimise disturbance to the system. Respiration rates were calculated as the slope of a linear function of $\mathrm{CO}_{2}$ concentration increase within the closed system over a period of $96 \mathrm{~s}$. Respiration measurements of all 3 blocks were always completed within $3 \mathrm{~h}$ and the order in which the blocks and transects within each block were measured was randomised each time. Measurements were conducted regularly through the full growing season in 2017 from bud swelling (08/06/17) to full leaf-out (23/06/17) and peak growing season (23-26/07/17) through to leaf senescence (22/09/17). A total of 11 repeated measurements were conducted at each collar. Additionally, on June 11th (12:00-16:40 h) $\mathrm{CO}_{2}$ flux measurements were taken with a clear chamber allowing photosynthesis as an estimate of understorey gross primary production (GPP). As the vegetation canopy in the forest is higher than the measurement chamber, respiration measured here is the sum of root, soil heterotroph and limited understorey leaf respiration $(65.2 \pm 31.3 \%$ cover $)$, referred to as respiration. Soil temperature and moisture were measured every hour at $5 \mathrm{~cm}$ depth using ONSET (Bourne, MA, USA) 12-Bit Temperature Smart Sensor and EC5 Soil Moisture Smart Sensor, respectively, logged on a HOBO microstation. Temperature response curves were generated for the entire growing season for all plots (seasonal $\mathrm{Q}_{10}$ values); however, data from trees not in full leaf and data from extremely dry days were excluded from the analysis due to the known breakdown of the temperature response at the extremes of low moisture (Sjögersten and Wookey 2002). We note that these fluxes incorporate both autotrophic and heterotrophic flux contributions, which vary throughout the growing season. Rather than being inherent temperature sensitivities of soil decomposition, these "virtual" $\mathrm{Q}_{10}$ values (sensu Subke and Bahn 2010), integrate total belowground metabolic activity, with higher values associated with areas of high autotrophic contributions during peak season.

\section{Hyphal in-growth}

Hyphal in-growth bags made of $6 \times 6 \mathrm{~cm} 37-\mu \mathrm{m}$ nylon mesh (allowing hyphal in-growth while excluding roots), and sealed with a heat sealer, were filled with $18 \mathrm{~g}$ of sand from the shore of lake Torneträsk $\left(68^{\circ} 21^{\prime} \mathrm{N}, 18^{\circ} 49^{\prime} \mathrm{E}\right)$ that had been washed, sieved and autoclaved twice before being oven dried. Individual hyphal in-growth bags were deployed on June 12th 2017, $15 \mathrm{~cm}$ to the left (when facing the tree) of each PVC collar along each transect, creating a parallel transect. Each hyphal in-growth bag was flattened to ensure an even width of approximately $0.5 \mathrm{~cm}$ in each bag. This

Table 1 Soil organic carbon (SOC) content, understorey gross primary productivity (GPP) and collar vegetation ( \pm Standard Error) along transects extending $3 \mathrm{~m}$ from individual trees

\begin{tabular}{|c|c|c|c|c|c|c|}
\hline \multirow{2}{*}{$\begin{array}{l}\text { Distance from } \\
\text { tree }(\mathrm{cm})\end{array}$} & \multirow{2}{*}{$\begin{array}{l}\text { Soil organic carbon } \\
\text { stocks }\left(\mathrm{kg} \mathrm{m}^{-2} \pm \mathrm{SE}\right)\end{array}$} & \multirow{2}{*}{$\begin{array}{l}\text { Understorey GPP } \\
\left(\mu \mathrm{mol} \mathrm{C} \mathrm{m}{ }^{-2} \mathrm{~s}^{-1} \pm \mathrm{SE}\right)\end{array}$} & \multicolumn{4}{|c|}{ Collar vegetation cover $(\% \pm \mathrm{SE})$} \\
\hline & & & $\begin{array}{l}\text { Vaccinium } \\
\text { vitis-idaea }\end{array}$ & Crypto-gams & Empetrum nigrum & Total vegetation \\
\hline 25 & $4.70 \pm 0.48$ & $-2.33 \pm 0.54$ & $37.8 \pm 9.4$ & $2.2 \pm 0.9$ & $21.4 \pm 10.6$ & $63.3 \pm 10.8$ \\
\hline 50 & $4.94 \pm 0.97$ & $-2.08 \pm 0.41$ & $25.4 \pm 6.6$ & $13.0 \pm 6.3$ & $18.0 \pm 10.1$ & $56.4 \pm 11.6$ \\
\hline 75 & $3.91 \pm 0.72$ & $-1.95 \pm 0.50$ & $22.1 \pm 4.1$ & $11.2 \pm 5.3$ & $18.8 \pm 8.4$ & $55.8 \pm 12.4$ \\
\hline 100 & $3.41 \pm 0.66$ & $-3.08 \pm 0.64$ & $23.8 \pm 4.6$ & $20.0 \pm 8.9$ & $36.1 \pm 13.3$ & $83.2 \pm 8.8$ \\
\hline 200 & $2.57 \pm 0.36$ & $-2.46 \pm 0.63$ & $37.7 \pm 10.5$ & $6.6 \pm 2.6$ & $14.4 \pm 4.4$ & $61.6 \pm 11.0$ \\
\hline 300 & $2.55 \pm 0.33$ & $-2.12 \pm 0.79$ & $23.6 \pm 4.9$ & $10.2 \pm 4.3$ & $32.2 \pm 8.4$ & $71.0 \pm 7.0$ \\
\hline$P$ value & 0.02 & 0.94 & 0.79 & 0.99 & 0.50 & 0.48 \\
\hline
\end{tabular}

$P$ values refer to the significance of the effect of distance from trees 
geometry was chosen to allow hyphae from various mycorrhizal species to grow into and explore through the sand depleted of organic carbon and into the organic carbon rich soil on the other side, thereby avoiding biasing for any particular species according to their characteristic ability to grow in low nutrient environments. Each bag was deployed in the organic soil horizon (just below the litter layer) at a $45^{\circ}$ angle from the vertical (both to provide good contact with the soil, but also to avoid any biases associated with lateral or geotropic hyphal growth), thus covering a vertical depth of approximately $4 \mathrm{~cm}$.

All hyphal in-growth bags were harvested on September 17th 2017, resulting in a total of 97 days in the organic soil layer. Bags were transported to the research station within $4 \mathrm{~h}$ of retrieval, and all content transferred to sterile plastic bags. Samples were stored at $-80^{\circ} \mathrm{C}$ for 3 days, then freeze-dried for $72 \mathrm{~h}$ in a ModulyoD freeze drier (ThermoFisher Scientific, Waltham, MA, USA). The majority of in-grown hyphae are assumed to originate from ECMs, as found by Wallander et al. (2001).

Hyphae were extracted by suspending $1.5 \mathrm{~g}$ of sand in $25 \mathrm{ml}$ deionised water and sonicating the solution for $10 \mathrm{~min}$. The separated hyphae and $10-15 \mathrm{ml}$ water solution were aliquoted into a $15-\mathrm{ml}$ falcon tube to allow mixing and further separation of hyphae from sand. This was then passed through a Büchner funnel with 25-mm glass microfiber filters (Whatman TM). The hyphae-filter matrix was then analysed for carbon content using a FLASH SMART elemental analyser (ThermoFisher Scientific, Waltham, MA, USA) after drying for $72 \mathrm{~h}$ at $50^{\circ} \mathrm{C}$. This process was repeated for 8 laboratory blank samples that had not been incubated in the field and the percentage carbon content $(0.34 \pm 0.05 \% \mathrm{C})$ was subtracted from all samples before further data processing.

\section{Root in-growth}

Root in-growth bags of $2 \mathrm{~mm}$ plastic mesh were constructed from $8 \times 9 \mathrm{~cm}$ squares of mesh resulting in a final height of $\sim 5 \mathrm{~cm}$ and a cross-sectional area of $\sim 3 \mathrm{~cm}^{2}$ after being filled and sealed using a heat sealer. The bags were loosely filled with organic soil collected from the tundra adjacent to the studied forest plots to mimic the loose structure of the organic soils within the forest. The collected soil was first oven dried at $85{ }^{\circ} \mathrm{C}$ for $48 \mathrm{~h}$ and sieved to $4 \mathrm{~mm}$ with most roots removed, but some small root fragments remaining. The bags were filled with $3.78 \pm 0.34 \mathrm{~g}$ (mean \pm standard deviation) of soil (average amount based on 10 randomly selected filled bags). Once filled, the bags were submerged overnight in deionised water to re-wet the dried soil and minimise loss of soil during transportation and deployment. All root in-growth bags were deployed on June 15th 2017. One root in-growth bag was deployed approximately $15 \mathrm{~cm}$ to the right (when facing the tree) of each PVC collar along the transect creating a parallel transect. A $2 \mathrm{~cm}$ diameter soil corer was used to extract a soil core to $5 \mathrm{~cm}$ depth and the root in-growth bag was inserted into the resulting hole. All root in-growth bags were harvested on September 15th 2017, giving a total of 92 days in the organic layer, incorporating the majority of the root growing season in subalpine birch forests in the Scandinavian subarctic (Blume-Werry et al. 2016). The bags were harvested using surgical grade scalpels to carefully cut any roots growing through the mesh to ensure all new root mass was maintained within the bag. In the lab, any roots protruding out of the mesh were cut off and discarded before the bags were opened; all new roots were collected and washed by finely examining the soil within each bag individually. Roots were not differentiated as originating from birch trees or ericoid shrubs. The new roots were oven dried at $60^{\circ} \mathrm{C}$ for 5 days and weighed.

\section{Soil core sampling}

Soil cores were taken during root in-growth bag deployment. The full organic horizon depth was measured and the top $5 \mathrm{~cm}$ of the organic soil horizon was retained and stored at $-18{ }^{\circ} \mathrm{C}$ for further analysis. Subsequently, samples were oven dried at $75^{\circ} \mathrm{C}$ for $72 \mathrm{~h}$ and soil organic matter (SOM) content for each sample determined by loss on ignition in a furnace at $550{ }^{\circ} \mathrm{C}$ for $4 \mathrm{~h}$ (Ball 1964). Organic soil bulk density for forested areas in the Abisko forests is $0.115 \pm 0.043 \mathrm{~g} \mathrm{~cm}^{-3}$ (mean \pm $\mathrm{SD}, n=24)$ and SOM was converted to soil organic carbon (SOC) content using the formula: $\mathrm{SOC}=$ $\mathrm{SOM}^{*} 0.5248$, parameterized based on extensive data on the relationship between SOM and soil C content around this area (Parker et al. 2015).

\section{Standing litter}

Standing litter along transects was collected from a $25 \times$ $25 \mathrm{~cm}$ area next to each collar on June 11th 2018. Collected litter was sorted into intact birch leaves and fragmented litter (including some litter from understorey 
species). The litter was dried at $60{ }^{\circ} \mathrm{C}$ for $24 \mathrm{~h}$ and weighed.

\section{DNA extraction and $q P C R$}

DNA was extracted from homogenous, representative soil samples using a DNeasy PowerSoil kit (Quiagen, Hilden, Germany) following the manufacturer's instructions. Extracted DNA was diluted 1:10 for qPCR reactions. Several different sets of primers were tested before the eventual selection of primers below. This selection was based on suitable amplicon length for the standards used. qPCR was run on a Step-One ${ }^{\mathrm{TM}}$ RealTime PCR system (Applied Biosystems) using the thermocycle programme described in Fierer and Jackson (2005) for Eub338/Eub518 primers, and May et al. (2001) for NS1/GCfung primers. Gradient PCR was performed on a Veriti 96-Well thermocycler (Applied Biosystems) prior to $\mathrm{qPCR}$ to validate the annealing temperatures. Primers used for 'All fungi' were NS1 (5'-GTA GTC ATA TGC TTG TCT -3') (White et al. 1990) and GCFung (with GC clamp removed) (5'-CAT TCC CCG TTA CCC GTT $-3^{\prime}$ ) (May et al. 2001). Primers used for 'All bacteria' were Eub338 (5'-ACT CCT ACG GGA GGC AGC AG3') and Eub518 (5'-ATT ACC GCG GCT GCT GG-3') (Fierer and Jackson 2005). Each $20 \mu$ reaction contained $10 \mu \mathrm{l}(2 \mathrm{x})$ PerfecTA SYBR Green Fastmix with ROX (QuantaBio, Maine, USA), $1.25 \mu \mathrm{l}$ of each forward and reverse primer, $1.25 \mu \mathrm{l}\left(20 \mathrm{mg} \mathrm{ml}^{-1}\right) \mathrm{BSA}, 2 \mu \mathrm{l}$ DNA template and $4.25 \mu \mathrm{l}$ nuclease free water. Two technical repeats were run per sample. Standards were created using Pseudomonas putida and Saccharomyces cerevisiae DNA with bacterial and fungal primers respectively. The resulting PCR product was cleaned using Wizard® SV Gel and PCR clean-up system (Promega, UK) and quantified by UV spectrophotometer (NanoDrop 2000, Thermo Scientific). Standard DNA was serially diluted by $1: 10$ and 5 point repeated standard curves were generated for bacteria $\left(10^{9}-10^{4}\right.$, excluding $\left.10^{7}\right)$ and fungi $\left(10^{7}-10^{3}\right)$. All standard curves had $\mathrm{R}^{2}>$ 0.99. Melt curve analysis was performed for all samples and standards to confirm a single product.

Statistical analysis

Variation in respiration, root production and hyphal production along transects was investigated using a linear mixed effects model (Pinheiro et al. 2017) with block, tree and collar assigned as random effects, accounting for variation between sampling dates. Parametric bootstrapping $(\times 1000)$ was used to predict $95 \%$ confidence intervals of the model. Tree basal area and vegetation cover were removed as covariates from the model as they did not significantly improve the model fit as measured by Akaike Information Criterion (AIC values. SOC content and vegetation cover were analysed using a similar method with block and tree as random effects. Seasonal $\mathrm{Q}_{10}$ values were modelled for each collar individually using the non-linear model fit $n l s . l m$ in R package minpack.lm (Elzhov et al. 2016) following the exponential regression: $\mathrm{SR}=\operatorname{Rate} 0 \mathrm{Q}_{10}{ }^{(\mathrm{T} / 10)}$, where $\mathrm{SR}$ is fitted soil $\mathrm{CO}_{2}$ efflux, Rate 0 is the basic respiration rate at $0{ }^{\circ} \mathrm{C}$ (y-axis intercept), $Q_{10}$ is the fitted temperature sensitivity, and $\mathrm{T}$ is soil temperature .

All analyses was carried out using R Version 3.4.0.

\section{Results}

Respiration

Respiration showed no significant differences $(P=0.22)$ between each point measured along transects extending $3 \mathrm{~m}$ radially from the base of mountain birch trees. A linear mixed effects model (Fig. 2a) predicts no difference in respiration $\leq 3 \mathrm{~m}$ away from the nearest tree. By contrast, at all points along transects, we found variation by a factor of 2-4 between replicate trees measured.

However, when respiration along transects is presented per unit SOC (Fig. 2b), rather than per unit area, there is a significant $(P=0.0003)$ increase in respiration per unit SOC with increasing distance from the tree.

The SOC stocks $(P=0.02$; Table 1$)$ and total standing litter $(P=0.0009$; Supp. Figure 2$)$ are significantly negatively related to distance from the tree. By contrast, understorey gross primary production (GPP), measured on 11 June 2017 as the difference in $\mathrm{CO}_{2}$ production in dark versus full sunlight conditions, did not vary significantly along the $3 \mathrm{~m}$ transects $(P=0.94$; Table 1$)$.

The composition and total coverage of vegetation within the collars used for respiration measurements along transects did not vary significantly with distance $(P=0.31$; Table 1$)$.

Root and hyphal production

There was no significant difference in either total root $(P=0.69)$ or hyphal $(P=0.14)$ production along 


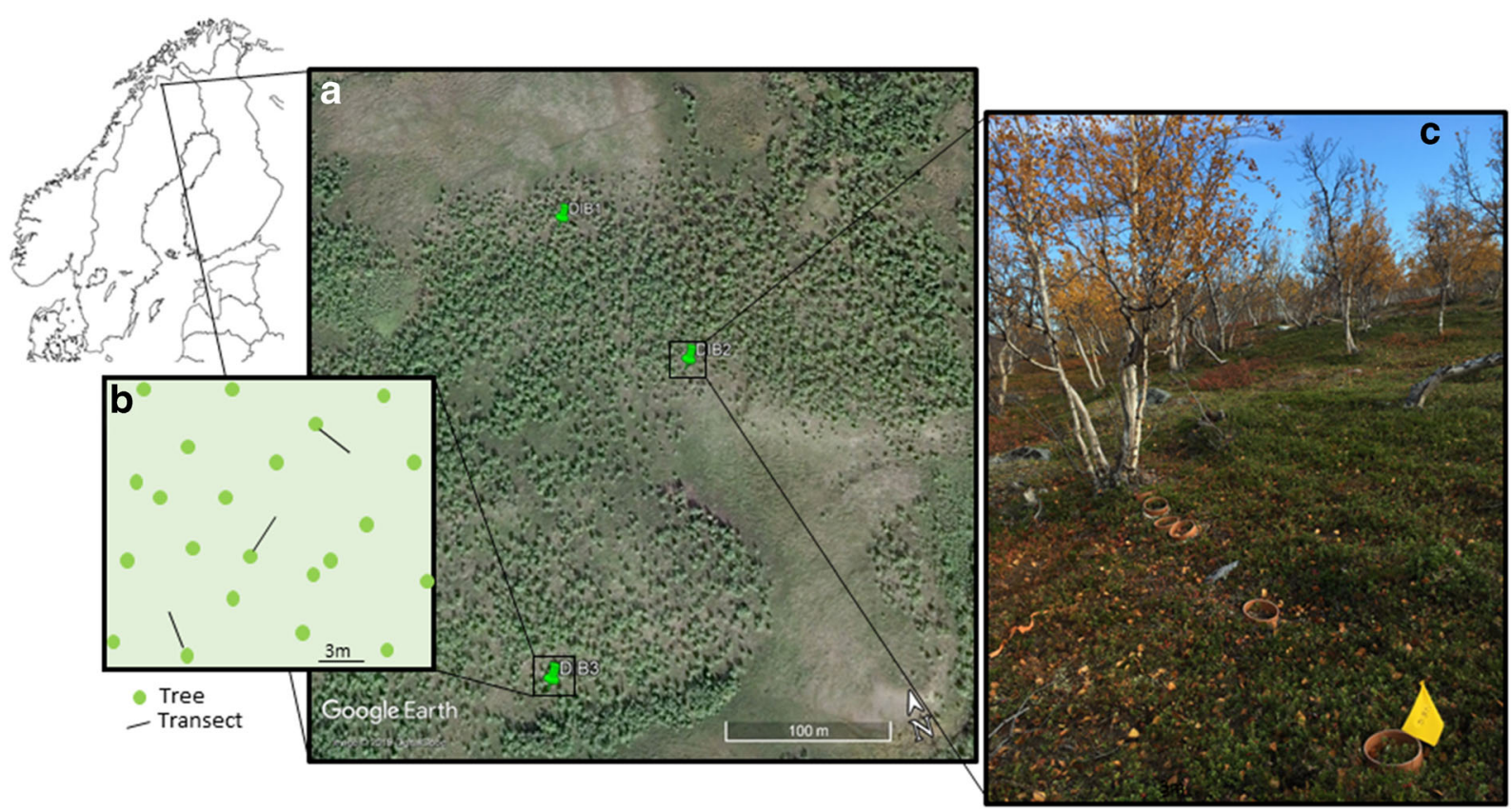

Fig. 1 Site map and transect set ups. a Site map of blocks in the open mountain birch forest south of Abisko. b Representative schematic of transects extending $3 \mathrm{~m}$ into forest gaps. $\mathbf{c}$ Photo of transect at block 2

transects over growing season (Fig. 3), with high levels of variation between replicate trees observed in both root and hyphal production. There was no significant difference $(P=0.31)$ with distance from tree when roots were normalised by $\%$ total vegetation cover. Corresponding to patterns observed in root and hyphal production, the seasonal $\mathrm{Q}_{10}$ (Fig. 8), does not vary significantly $(P=$ 0.223 ) along transects extending from tree bases (Fig. 4).

\section{Soil microbial communities}

The quantity of neither total fungi $(P=0.082)$ nor total bacteria $(P=0.97)$ varied significantly with distance from trees (Fig. 5a). These data were used to generate a fungi:bacteria ratio along the transect and here, by contrast, there is a significantly decreasing relationship, declining by $0.077 \pm 0.035$ per $\mathrm{m}(P=0.035)$ with increasing distances from trees (Fig. 5b).

\section{Discussion}

Through systematic measurements of key soil processes at varying distances from trees, we found no significant trends in respiration and mycorrhizosphere productivity within mesic mountain birch forests (Hypotheses 1 and
2 are therefore not supported by the data). We did, however, detect a significant increase in the ratio of fungi:bacteria with increasing distance from trees (Fig. $5 b$ ), providing support for Hypothesis 3 . By contrast, we noted that litter fall and SOC declined significantly with increasing distance from trees (Figs. 2 and 3 and 7 , Table 1), supporting Hypothesis $4 \mathrm{a}$, but not $4 \mathrm{~b}$. These findings are summarised graphically in Fig. 6.

The lack of significant trends in mycorrhizosphere productivity does not signify homogeneity in these soils, as high levels of variation between studied trees were apparent (Figs. 1 and 2). This lack of a clear spatial trend in mycorrhizosphere productivity, however, is particularly relevant in the context of the open structure of treeline ecotone forests. With 2-7 m between trees (Table 1), a $3 \mathrm{~m}$ transect represents the likely maximum distance obtainable from the nearest tree base without being closer to a neighbouring tree. Thus, if root and hyphal production show no significant trends on a scale of up to $3 \mathrm{~m}$ with respect to the nearest tree, then it can be hypothesized that this lack of pattern reflects efficient exploitation of the soil resource by root and ECM networks extending throughout these forests (given similar environmental and edaphic contexts). The influence of trees on soil processes such as respiration and mycorrhizosphere productivity up to (and potentially 
Fig. 2 Respiration along transects extending $3 \mathrm{~m}$ from birch trees. a Respiration per unit soil area and $\mathbf{b}$ respiration per unit soil organic carbon. Solid line is predicted respiration based on a linear mixed effects model. Points are means at the given distance for each of the 11 measurement days. Grey polygon indicates $95 \%$ confidence bands of the predicted line
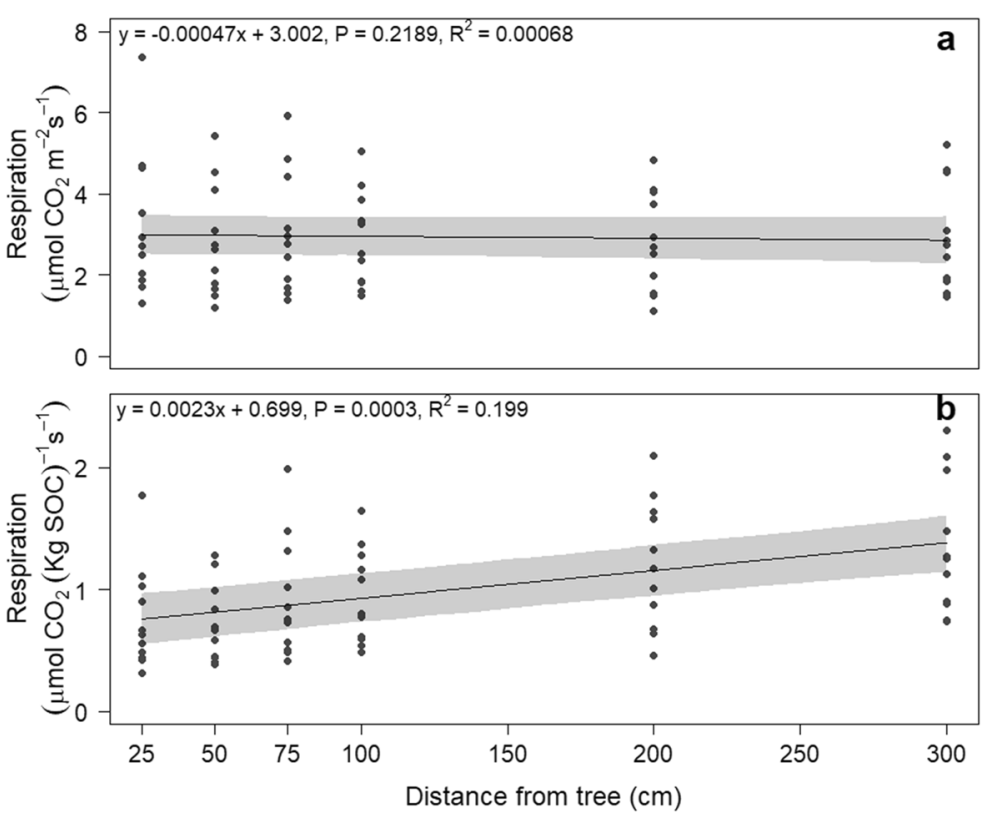

beyond) $3 \mathrm{~m}$ away from trees is further supported by similar mean seasonal $\mathrm{Q}_{10}$ values across all measured distances along the transect (Figs. 4 and 8).

The absence of a trend in respiration and mycorrhizosphere productivity with increasing distance from trees within the forest does not support our original Hypotheses 1 and 2. These findings therefore also contrast with those of Parker et al. (2016), where systematic declines in respiration were noted $150 \mathrm{~cm}$ away from tree bases compared with $50 \mathrm{~cm}$. It should be noted, however, that Parker et al. (2016) reported fewer fine scale spatial measurements and lower levels of replication than the current work. Our results are also in accordance with $46 \%$ of reviewed datasets in a recent meta-analysis across plant communities, which found no significant horizontal spatial variation in ectomycorrhizal communities (Bahram et al. 2015). The lack of spatial variation with respect to respiration and mycorrhizosphere productivity found here may be linked to widespread activity of birch tree roots, ectomycorrhizas and bacteria, directly or indirectly contributing to organic matter and soil carbon decomposition and nutrient cycling (Bödeker et al. 2016; Lindahl and Tunlid 2015; Talbot et al. 2008).

Despite the lack of trends mediated by trees on respiration and mycorrhizosphere production, we identified a significant decline in SOC stocks with increasing distance from trees (Table 1), from which we can infer a difference in $\mathrm{C}$ accumulation rates and/or turnover with distance from trees (Hypotheses $4 \mathrm{a}$ and $4 \mathrm{~b}$ ). A decline in
SOC with increasing distance from the tree, or build-up of SOC closer to the tree, is likely a result of higher litter inputs (Fig. 7), or higher fungi:bacteria (Fig. 5b) ratio (and thus slower decomposition; Hypotheses 3 and 4), or a combination thereof. Respiration data (Fig. 2a) indicate that higher litter inputs close to the tree are not associated with higher rates of decomposition, which implies that, despite the apparent higher availability of $\mathrm{C}$ closer to trees, there is not a corresponding increase in microbial activity. This may reflect litter recalcitrance or slowed $\mathrm{C}$ turnover in ectomycorrhizal dominated soils potentially hampering early stage decomposition (Sterkenburg et al. 2018). Although we could not detect a trend in respiration per unit area, there was a clear increase in respiration per unit SOC with increasing distance from trees (Fig. 2b). This shows greater respiration per unit resource (specifically, here, carbon) available to heterotrophs further away from the tree (thus not supporting Hypothesis $4 \mathrm{~b}$ ). Greater respiration per unit SOC indicates higher potential for SOC loss if the carbon use efficiency (CUE) - the proportion of $\mathrm{C}$ assimilated by the microbial community relative to $\mathrm{C}$ lost through respiration - is low (Cotrufo et al. 2013; Sauvadet et al. 2018; Kallenbach et al. 2019). Furthermore, this suggests that the proportion of total respiration facilitated by the rhizosphere (roots and ECM) is larger further away from the tree (Fig. 4), consistent with declining SOC stocks (and leaf litter inputs) at increasing distances from trees. Larger relative influence of the 
Fig. 3 Root (a) and hyphal (b) production for 92 and 97 days respectively during the growing season 2017 in in-growth bags along transects extending $3 \mathrm{~m}$ from individual trees. Solid line is predicted root production based on a linear mixed effects model. Grey polygon indicates $95 \%$ confidence bands of the predicted line
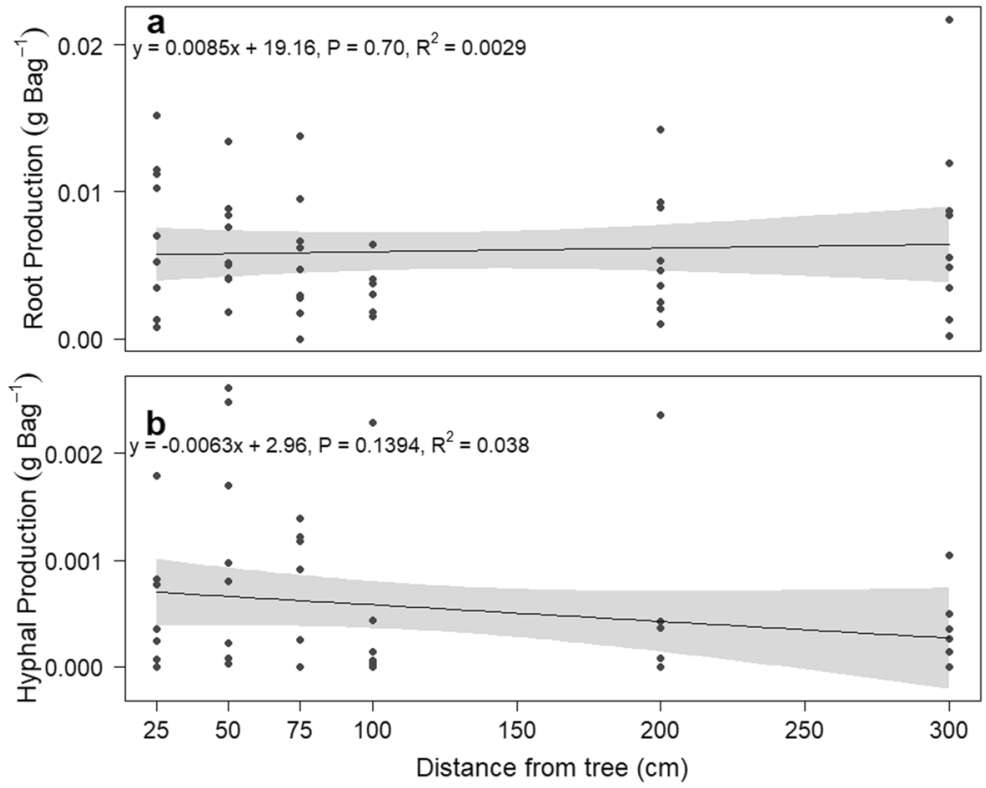

rhizosphere suggests an increase in root and microbial activity further away from trees, with potentially low CUE, as there is no change in root and hyphal production along transects. Increased peripheral activity may result from competition between root and hyphal networks associated with neighbouring trees (Boddy 2000) and provides tantalising, although indirect, evidence for larger autotrophic contributions to respiration and potentially rhizosphere priming of the soil heterotrophic community (Fig. 6) (Fontaine et al. 2007; Wild et al. 2016). The current study does not, however, allow us to allocate the respiration signal to various $\mathrm{C}$ sources originating from many potential $\mathrm{C}$ pools within the ecosystem, and therefore caution must be applied when interpreting results.
Key soil processes, such as $\mathrm{C}$ turnover and storage, relate to the diversity of morphotypes (ECM or ERM, inferred here based on aboveground vegetation being ericaceous shrubs or Betula spp.), growth forms and exploration types of the mycorrhizal community (Cornelissen et al. 2001; Clemmensen et al. 2013, 2015; Hazard and Johnson 2018). Changes in soil microbial community composition along transects could be examined in more detail using appropriate sequencing techniques to identify microbial species present. Here we find that, although production rates of roots and hyphae remained consistently high up to $3 \mathrm{~m}$ from trees within the forest, there was a decline in the fungi:bacteria ratio, and therefore potential $\mathrm{C}$ storage (Bailey et al. 2002). The apparent discrepancy between
Fig. 4 Change in seasonal $\mathrm{Q}_{10}$ with increasing distance from trees. Seasonal $\mathrm{Q}_{10}$ values generated from temperature response curves in Fig. 5. Grey polygon indicates $97.5 \%$ confidence band of the predicted line. Error bars represent standard error of replicates at each distance from trees

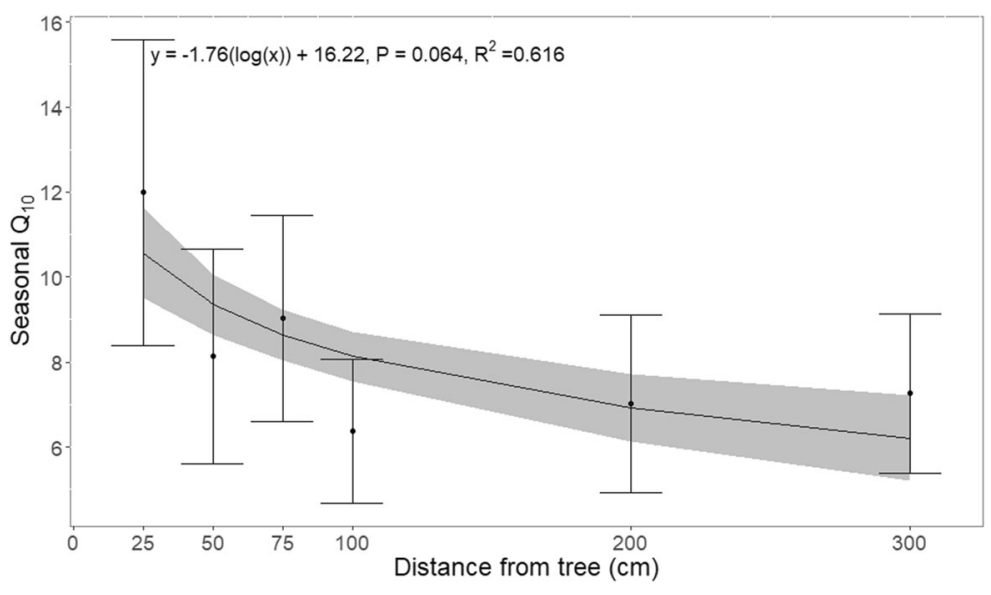


Fig. 5 Abundance (a) and ratio (b) of fungi and bacteria along $3 \mathrm{~m}$ transects extending away from trees. Solid lines are predicted based on a linear mixed effects model. Opaque polygons indicate $97.5 \%$ confidence bands of the predicted lines
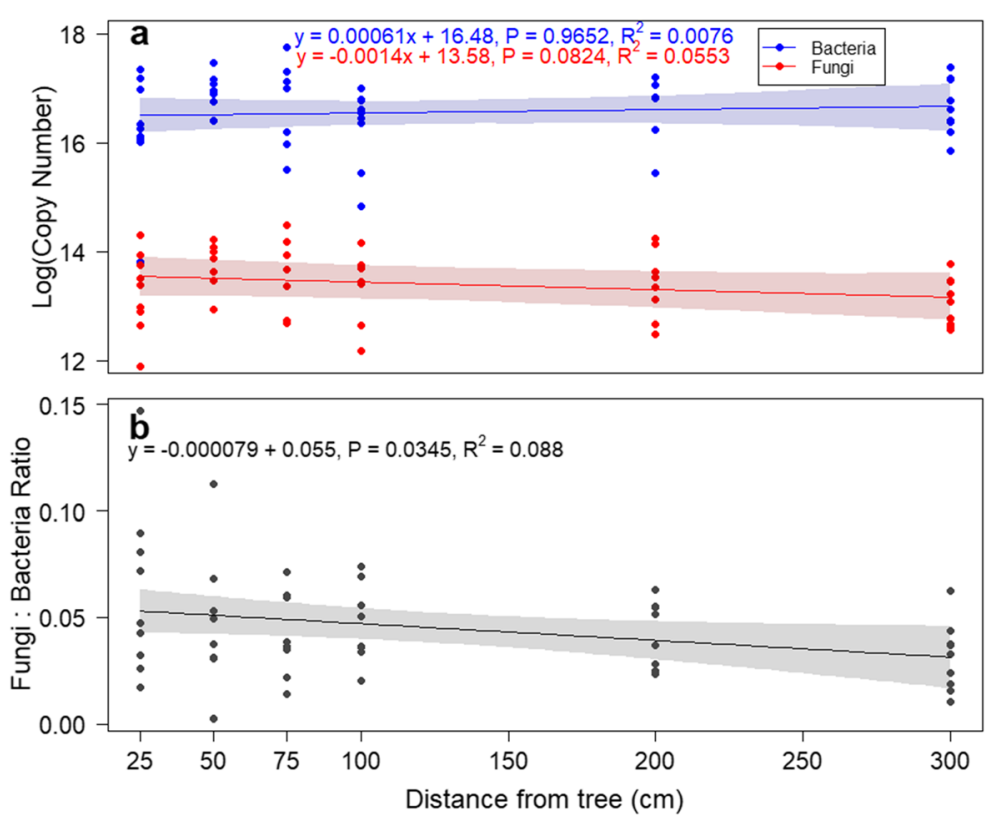

hyphal production and fungi:bacteria ratio may be explained by an inability of the hyphal production assay to detect small changes in abundance detectable at a molecular level, or by variation in the abundance of bacteria or saprotrophic fungi, as the primers used are not ECM specific. This pattern may, in part, be caused by the dependence of saprotrophic fungi on $\mathrm{C}$ inputs in the form of birch tree litter, which decrease with increasing distance from trees (Fig. 7) and are more labile than understorey litter (Parker et al. 2018). Variation in standing litter is likely to cause spatial heterogeneity within the saprotrophic community not seen in mycorrhizal fungi communities, which receive plant photosynthates directly (Lindahl et al. 2007).

Our evidence for patchiness of SOC stocks in birch forests should be interpreted in the context of forest succession patterns, as varying SOC stocks and $\mathrm{C}$ accumulation in relation to individual trees may be linked to historical demographics and turnover (i.e. the forest seen today is merely a snapshot of a dynamic ecosystem (Callaghan et al. 2002; Van Bogaert et al. 2011). Without the ongoing recruitment and deaths of trees, there might be net
Fig. 6 Schematic diagram summarising soil processes measured in this study at varying distances away from individual trees. The partitioning of respiration explained by treemediated inputs is based on the data presented here, but requires further investigation. SOC: Soil Organic Carbon

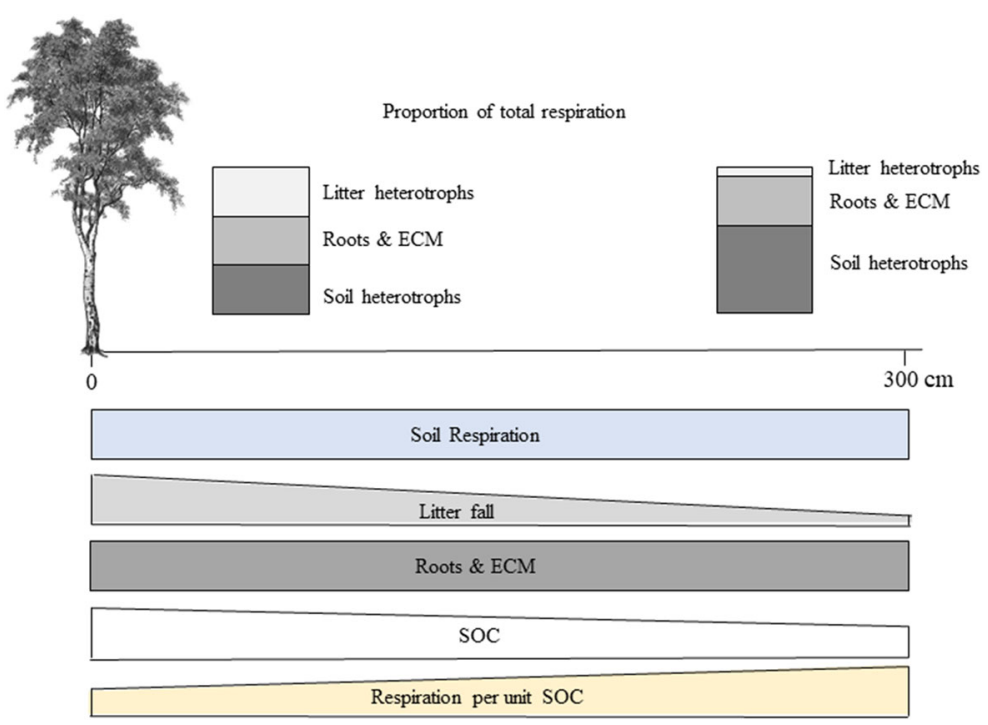


accumulation of SOC close to trees, and net loss of SOC further away from trees. However, with on-going turnover - tree death, and establishment of trees in forest gaps - the development, persistence and magnitude of spatial patterns in SOC stocks at contrasting distances from living trees will be related both to forest dynamics as well as soil organic matter turnover. Slow population turnover would lead to increasingly patchy SOC stocks driven by trees. However, establishment of trees in forest gaps on shorter time scales, could facilitate re-accumulation of lost SOC by new trees in forest gaps. In Fennoscandian Lapland, trees can be 200 years old (Tømmervik et al. 2009), but age varies significantly $(86 \pm 43$ years $($ mean $\pm S D)$; Millar (1980)) with a high density of mountain birch seedlings/ saplings ( $\sim 1800 \mathrm{ha}^{-1}$ of $\leq 1.5 \mathrm{~m}$ height and $\leq 15 \mathrm{~mm}$ basal stem diameter; B. Dick, pers. comm.). Decaying tree stumps are also evident and important as the influence of a single tree may be long lasting, given the microbial community it sustained whilst alive, and will influence future microbial communities after death (Clemmensen et al. 2013; Fernandez et al. 2016; Godbold et al. 2006; Varik et al. 2013). Furthermore, cyclical defoliating Epirrita moth outbreaks occur in this area on decadal timescales (Olsson et al. 2017; Tenow and Bylund 2000) causing tree loss or increased polycormy. Taken together, the timescales of forest dynamics may enable development of patchy SOC stocks related to individual trees, as found here. This further illustrates the complexity of soil C dynamics (Sulman et al. 2018) and emphasises the importance of long-term measurements and integration of biological traits with soil processes for global change modelling and predicting Arctic responses to climate change at plot and vegetation levels (Shaver et al. 2013; Wurzburger and Clemmensen 2018).

Based on our measurements, we suggest that the influence of an individual mountain birch tree within these forests extends at least $3 \mathrm{~m}$ from the main stem, far exceeding the average crown diameter $(167 \pm 35 \mathrm{~cm}$; Table 3). This influence includes continued high production rates of fine roots and ectomycorrhizas to at least $3 \mathrm{~m}$ away from trees, with the ectomycorrhizal network likely to extend further beyond that of the root network (Anderson and Cairney 2007; Simard and Durall 2004). The spatial distribution and range of ectomycorrhizal hyphae depends on fine root distribution (Pickles et al. 2010) and mycorrhizal taxa (Agerer 2001), but mycelia have been demonstrated to extend up to $9.6 \mathrm{~cm}$ away from mycorrhizal root tips, depending on exploration types (Weigt et al. 2012). Although we lack direct evidence, the wide ranging influence and extent of the birch mycorrhizosphere and associated ectomycorrhizas in this area provides a tantalizing suggestion of the presence of a wood-wide-web and the potential for common mycelial networks (CMNs) (Beiler et al. 2010; Johnson 2015; Peter 2006; Selosse et al. 2006). The ability of ectomycorrhizas to colonise multiple host plants, and thereby create a cytoplasmic link through which nutrients (He et al. 2003; Selosse et al. 2006) and signalling molecules (Babikova et al. 2013) can be exchanged, has been well documented in the lab (Arnebrant et al. 1993; Finlay and Read 1986; Pickles et al. 2017). However, there are very few studies of CMNs in the field (Deslippe and Simard 2011; Simard et al. 1997) and, to our knowledge, none on mountain birch trees in the Arctic. Deslippe and Simard (2011) found transfer of $C$ between conspecific pairs of dwarf birch (Betula nana L.) in the Alaskan Arctic and argued that the magnitude of this $C$ transfer may alter competitive plant interactions in the arctic tundra. The implications of the potential presence of common mycelial networks in the Arctic, and in other regions, could be profound for forest health, $\mathrm{C}$ turnover and stocks, both above- and belowground.

\section{Conclusions}

Here we have focussed on the influence of mountain birch trees within forests on key soil processes such as respiration, SOC stocks, root and mycorrhizal production and microbial community abundance in an ecotone forest in sub-Arctic Sweden. We conclude that the direction, strength and magnitude of spatial trends within the forest floor in relation to proximal trees vary greatly. Our results show spatial variation in $\mathrm{C}$ accumulation rates in relation to nearest trees through changes in SOC stocks and litter fall. Contrastingly, we find no trend in respiration with distance from trees, likely mediated by an extensive root and ectomycorrhizal network of the birch trees, which efficiently exploit resources throughout the forest. This is an early indication of a 'wood-wide-web' in these forests. Further investigation is required, however, to understand the extent and significance of such a network. Recognising the interactions between the aboveground vegetation and belowground soil processes, and the soil $\mathrm{C}$ cycles that they mediate, is crucial in these globally important subArctic ecosystems undergoing climate change. 
Acknowledgements The research leading to these results has received funding from the European Union's Horizon 2020 project INTERACT, under grant agreement No 730938. We extend our warm thanks to staff at the Abisko Scientific Research Station for hosting us and for supporting this work. We would also like to thank Ian Washbourne, Alyssa Parker, Ilona Kater and Gwen Lancashire for assistance in the field and processing of lab samples as well as Dr. Gaius R. Shaver for an extensive pre-submission review and Gerald Emmans for comments on an earlier version of this manuscript.

Data Availability All transect data including: respiration, root production, hyphae production, GPP, soil characteristics, vegetation cover, standing litter and molecular qPCR data will be added to the Dryad Data Repository upon acceptance.

Open Access This article is licensed under a Creative Commons Attribution 4.0 International License, which permits use, sharing, adaptation, distribution and reproduction in any medium or format, as long as you give appropriate credit to the original author(s) and the source, provide a link to the Creative Commons licence, and indicate if changes were made. The images or other third party material in this article are included in the article's Creative Commons licence, unless indicated otherwise in a credit line to the material. If material is not included in the article's Creative Commons licence and your intended use is not permitted by statutory regulation or exceeds the permitted use, you will need to obtain permission directly from the copyright holder. To view a copy of this licence, visit http://creativecommons.org/licenses/by/4.0/.

\section{References}

Agerer R (2001) Exploration types of ectomycorrhizae: a proposal to classify ectomycorrhizal mycelial systems according to their patterns of differentiation and putative ecological importance. Mycorrhiza 11:107-114. https://doi.org/10.1007 /s005720100108

Anderson IC, Cairney JWG (2007) Ectomycorrhizal fungi: exploring the mycelial frontier. FEMS Microbiol Rev 31:388406. https://doi.org/10.1111/j.1574-6976.2007.00073.x

Arnebrant K, Ek H, Finlay RD, Söderström B (1993) Nitrogen translocation between Alnus glutinosa (L.) Gaertn. seedlings inoculated with Frankia sp. and Pinus contorta Doug, ex Loud seedlings connected by a common ectomycorrhizal mycelium. New Phytol 124:231-242. https://doi. org/10.1111/j.1469-8137.1993.tb03812.x

Averill C, Hawkes CV (2016) Ectomycorrhizal fungi slow soil carbon cycling. Ecol Lett 19:937-947. https://doi. org/10.1111/ele.12631

Babikova Z, Gilbert L, Bruce TJA et al (2013) Underground signals carried through common mycelial networks warn neighbouring plants of aphid attack. Ecol Lett 16:835-843. https://doi.org/10.1111/ele.12115

Bahram M, Peay KG, Tedersoo L (2015) Local-scale biogeography and spatiotemporal variability in communities of mycorrhizal fungi 205:1454-1463. https://doi.org/10.1111 /nph.13206
Bailey VL, Smith JL, Bolton H (2002) Fungal-to-bacterial ratios in soils investigated for enhanced $\mathrm{C}$ sequestration. Soil Biol Biochem 34:997-1007. https://doi.org/10.1016/S0038-0717 (02)00033-0

Beiler KJ, Durall DM, Simard SW, Maxwell SA, Kretzer AM (2010) Architecture of the wood-wide web: Rhizopogon spp. genets link multiple Douglas-fir cohorts. New Phytol 185: 543-553. https://doi.org/10.1111/j.1469-8137.2009.03069.x

Blume-Werry G, Wilson SD, Kreyling J, Milbau A (2016) The hidden season: growing season is $50 \%$ longer below than above ground along an arctic elevation gradient. New Phytol 209:978-986. https://doi.org/10.1111/nph.13655

Boddy L (2000) Interspecific combative interactions between wood-decaying basidiomycetes. FEMS Microbiol Ecol 31: 185-194. https://doi.org/10.1016/S0168-6496(99)00093-8

Bödeker ITM, Lindahl BD, Olson Å, Clemmensen KE (2016) Mycorrhizal and saprotrophic fungal guilds compete for the same organic substrates but affect decomposition differently. Funct Ecol:1967-1978. https://doi.org/10.1111/13652435.12677

Callaghan TV, Werkman BR, Crawford RMM (2002) The tundrataiga interface and its dynamics: concepts and applications. Ambio Special Report:6-14. https://doi.org/10.2307 125094570

Clemmensen KE, Bahr A, Ovaskainen O, Dahlberg A, Ekblad A, Wallander H, Stenlid J, Finlay RD, Wardle DA, Lindahl BD (2013) Roots and associated fungi drive long-term carbon sequestration in boreal forest. Science 339:1615-1618. https://doi.org/10.1126/science.1231923

Clemmensen KE, Finlay RD, Dahlberg A et al (2015) Carbon sequestration is related to mycorrhizal fungal community shifts during long-term succession in boreal forests. New Phytol 205:1525-1536. https://doi.org/10.1111/nph.13208

Cornelissen J, Aerts R, Cerabolini B, Werger M, van der Heijden M (2001) Carbon cycling traits of plant species are linked with mycorrhizal strategy. Oecologia 129:611-619. https://doi.org/10.1007/s004420100752

Cotrufo MF, Wallenstein MD, Boot CM, Denef K, Paul E (2013) The microbial efficiency-matrix stabilization (MEMS) framework integrates plant litter decomposition with soil organic matter stabilization: do labile plant inputs form stable soil organic matter? Glob Chang Biol 19:988-995. https://oi.org/10.1111/gcb.12113

Dahlberg U, Berge TW, Peterson H, Vencatasawmy CP (2004) Modelling biomass and leaf area index in a sub-arctic scandinavian mountain area. Scand J For Res:60-71. https://doi. org/10.1080/02827580310019266

Deslippe JR, Simard SW (2011) Below-ground carbon transfer among Betula nana may increase with warming in Arctic tundra. New Phytol 192:689-698. https://doi.org/10.1111 j.1469-8137.2011.03835.x

Elzhov TV, Mullen KM, Spiess A-N, Bolker B (2016) minpack.lm: $\mathrm{R}$ interface to the Levenberg-Marquardt nonlinear least-squares algorithm found in MINPACK, plus support for bounds.1-2

Fernandez CW, Kennedy PG (2016) Revisiting the "Gadgil effect": Do interguild fungal interactions control carbon cycling in forest soils? New Phytologist 209:1382-1394. https://doi.org/10.1111/nph.13648

Fierer N, Jackson J (2005) Assessment of soil microbial community structure by use of taxon-specific quantitative PCR 
assays. Appl Environ Microbiol 71:4117. https://doi. org/10.1128/AEM.71.7.4117

Fierer N, Strickland MS, Liptzin D, Bradford MA, Cleveland CC (2009) Global patterns in belowground communities. Ecol Lett 12:1238-1249. https://doi.org/10.1111/j.14610248.2009.01360.x

Finlay RD, Read DJ (1986) The structure and function of the vegetative mycelium of ectomycorrhizal plants. I. Translocation of ${ }^{14} \mathrm{C}$-labeled carbon between plants interconnected by a common mycelium. New Phytol 103:143-156. https://doi.org/10.1111/j.1469-8137.1986.tb00603.x

Fontaine S, Barot S, Barré P et al (2007) Stability of organic carbon in deep soil layers controlled by fresh carbon supply. Nature 450:277-280. https://doi.org/10.1038/nature06275

Grayston SJ, Prescott CE (2005) Microbial communities in forest floors under four tree species in coastal British Columbia. Soil Biol Biochem 37:1157-1167. https://doi.org/10.1016/j. soilbio.2004.11.014

Godbold DL, Hoosbeek MR, Lukac M, et al (2006) Mycorrhizal hyphal turnover as a dominant process for carbon input into soil organic matter. Plant and Soil 281:15-24. https://doi. org/10.1007/s11104-005-3701-6

Hartley IP, Garnett M, Sommerkorn M et al (2012) A potential loss of carbon associated with greater plant growth in the European Arctic. Nat Clim Chang 2:875-879. https://doi. org/10.1038/nclimate1575

Hazard C, Johnson D (2018) Does genotypic and species diversity of mycorrhizal plants and fungi affect ecosystem function? New Phytol 220:1122-1128. https://doi.org/10.1111 /nph.15010

He X-H, Critchley C, Bledsoe C (2003) Nitrogen transfer within and between plants through common mycorrhizal networks (CMNs). Crit Rev Plant Sci 22:531-567. https://doi. org/10.1080/713608315

Högberg MN, Högberg P, Myrold DD (2007) Is microbial community composition in boreal forest soils determined by $\mathrm{pH}$, C-to-N ratio, the trees, or all three? Oecologia 150:590-601. https://doi.org/10.1007/s00442-006-0562-5

Iversen CM, Sloan VL, Sullivan PF, Euskirchen ES, McGuire A, Norby RJ, Walker AP, Warren JM, Wullschleger SD (2015) The unseen iceberg: plant roots in arctic tundra. New Phytol 205:34-58

Johnson D (2015) Priorities for research on priority effects. New Phytol 205:1375-1377

Kallenbach CM, Wallenstein MD, Schipanksi ME, Stuart Grandy A (2019) Managing agroecosystems for soil microbial carbon use efficiency: ecological unknowns, potential outcomes, and a path forward. Front Microbiol. https://doi. org/10.3389/fmicb.2019.01146

Karhu K, Auffret MD, Dungait JA, Hopkins DW, Prosser J, Singh BK, Subke JA, Wookey PA, Agren GI, Sebastià MT, Gouriveau F, Bergkvist G, Meir P, Nottingham AT, Salinas N, Hartley IP (2014) Temperature sensitivity of soil respiration rates enhanced by microbial community response. Nature 513:81-84. https://doi.org/10.1038/nature13604

Kuhry P, Grosse G, Harden JW et al (2013) Characterisation of the permafrost carbon pool. Permafr Periglac Process 24:146155. https://doi.org/10.1002/ppp.1782

Kullman L, Öberg L (2009) Post-little ice age tree line rise and climate warming in the Swedish Scandes: a landscape ecological perspective. J Ecol 97:415-429. https://doi. org/10.1111/j.1365-2745.2009.01488.x

Lindahl BD, Tunlid A (2015) Ectomycorrhizal fungi - potential organic matter decomposers, yet not saprotrophs. New Phytol 205:1443-1447. https://doi.org/10.1111/nph.13201

Lindahl BD, Boberg J, Trumbore SE et al (2007) Spatial separation of litter decomposition and mycorrhizal nitrogen uptake in a boreal forest. New Phytol:611-620. https://doi. org/10.1111/j.1469-8137.2006.01936.x

Luo Y (2007) Terrestrial carbon-cycle feedback to climate warming. Annu Rev Ecol Evol Syst 38:683-712. https://doi.org/10.1146/annurev.ecolsys.38.091206.095808

May LA, Smiley B, Schmidt MG (2001) Comparative denaturing gradient gel electrophoresis analysis of fungal communities associated with whole plant corn silage. Can J Microbiol 47: 829-841. https://doi.org/10.1139/cjm-47-9-829

Mitchell RJ, Hester AJ, Campbell CD et al (2010) Is vegetation composition or soil chemistry the best predictor of the soil microbial community? Plant Soil 333:417-430. https://doi. org/10.1007/s11104-010-0357-7

Olsson PO, Heliasz M, Jin H, Eklundh L (2017) Mapping the reduction in gross primary productivity in subarctic birch forests due to insect outbreaks. Biogeosciences 14:17031719. https://doi.org/10.5194/bg-14-1703-2017

Parker TC, Subke JA, Wookey PA (2015) Rapid carbon turnover beneath shrub and tree vegetation is associated with low soil carbon stocks at a subarctic treeline. Glob Chang Biol 21: 2070-2081. https://doi.org/10.1111/gcb.12793

Parker TC, Sadowsky J, Dunleavy H et al (2016) Slowed biogeochemical cycling in sub-arctic birch forest linked to reduced mycorrhizal growth and community change after a defoliation event. Ecosystems:316-330. https://doi.org/10.1007 /s10021-016-0026-7

Parker TC, Sanderman J, Holden RD, Blume-Werry G, Sjögersten S, Large D, Castro-Díaz M, Street LE, Subke JA, Wookey PA (2018) Exploring drivers of litter decomposition in a greening Arctic: results from a transplant experiment across a treeline. Ecology 99:2284-2294. https://doi.org/10.1002/ecy.2442

Payette S, Lavoie C (1994) The arctic tree line as a record of past and recent climatic change. Environ Rev 2:78-90. https://doi. org/10.1139/a94-004

Peter M (2006) Ectomycorrhizal fungi-fairy rings and the woodwide web. New Phytol 171:685-687. https://doi.org/10.1111 /j.1469-8137.2006.01856.x

Pickles BJ, Genney DR, Potts JM, Lennon JJ, Anderson IC, Alexander IJ (2010) Spatial and temporal ecology of scots pine ectomycorrhizas. New Phytol 186:755-768. https://doi. org/10.1111/j.1469-8137.2010.03204.x

Pickles BJ, Wilhelm R, Asay AK, Hahn AS, Simard SW, Mohn WW (2017) Transfer of ${ }^{13} \mathrm{C}$ between paired Douglas-fir seedlings reveals plant kinship effects and uptake of exudates by ectomycorrhizas. New Phytol 214:400-411. https://doi. org/10.1111/nph.14325

Ping C-L, Michaelson GJ, Jorgenson MT et al (2008) High stocks of soil organic carbon in the north American Arctic region. Nat Geosci 1:615-619. https://doi.org/10.1038/ngeo284

Pinheiro J, Bates D, DebRoy S, Sarkar D (2017) nlme: linear and nonlinear mixed effects models. $\mathrm{R}$ package version 3.0

Read DJ, Perez-Moreno J (2003) Mycorrhizas and nutrient cycling in ecosystems - a journey towards relevance? New Phytol 
157:475-492. https://doi.org/10.1046/j.14698137.2003.00704.x

Rueden CT, Schindelin J, Hiner MC et al (2017) ImageJ2: ImageJ for the next generation of scientific image data. BMC Bioinformatics 18:529

Rundqvist S, Hedenås H, Sandström A, Emanuelsson U, Eriksson H, Jonasson C, Callaghan TV (2011) Tree and shrub expansion over the past 34 years at the tree-line near Abisko, Sweden. Ambio 40:683-692. https://doi.org/10.1007 /s13280-011-0174-0

Sauvadet M, Lashermes G, Alavoine G et al (2018) High carbon use efficiency and low priming effect promote soil C stabilization under reduced tillage. Soil Biol Biochem 123:64-73. https://doi.org/10.1016/j.soilbio.2018.04.026

Selosse MA, Richard F, He X, Simard SW (2006) Mycorrhizal networks: des liaisons dangereuses? Trends Ecol Evol 21: 621-628. https://doi.org/10.1016/j.tree.2006.07.003

Shaver GR, Rastetter EB, Salmon V et al (2013) Pan-Arctic modelling of net ecosystem exchange of $\mathrm{CO}_{2}$. Philos Trans R Soc B 368:1-13. https://doi.org/10.1098/rstb.2012.0485

Simard SW, Durall DM (2004) Mycorrhizal networks: a review of their extent, function, and importance. Can J Bot 82:11401165. https://doi.org/10.1139/b04-116

Simard SW, Perry DA, Jones MD et al (1997) Net transfer of carbon between ectomycorrhizal tree species in the field. Nature 388:579-582. https://doi.org/10.1038/41557

Simard SW, Beiler KJ, Bingham MA et al (2012) Mycorrhizal networks: mechanisms, ecology and modelling. Fungal Biol Rev 26:39-60. https://doi.org/10.1016/j.fbr.2012.01.001

Six J, Frey SD, Thiet RK, Batten KM (2006) Bacterial and fungal contributions to carbon sequestration in agroecosystems. Soil Sci Soc Am J 70:555. https://doi.org/10.2136 /sssaj2004.0347

Sjögersten S, Wookey PA (2002) Climatic and resource quality controls on soil respiration across a forest - tundra ecotone in Swedish Lapland. Soil Biol Biochem 34:1633-1646. https://doi.org/10.1016/S0038-0717(02)00147-5

Smith SE, Read D (2008) Mycorrhizal Symbiosis. Academic Press, New York

Sterkenburg E, Clemmensen KE, Ekblad A, Finlay RD, Lindahl BD (2018) Contrasting effects of ectomycorrhizal fungi on early and late stage decomposition in a boreal forest. ISME J 12:2187-2197. https://doi.org/10.1038/s41396-018-0181-2

Strickland MS, Rousk J (2010) Considering fungal: bacterial dominance in soils - methods, controls, and ecosystem implications. Soil Biol Biochem 42:1385-1395. https://doi. org/10.1016/j.soilbio.2010.05.007

Subke JA, Bahn M (2010) On the "temperature sensitivity" of soil respiration: can we use the immeasurable to predict the unknown? Soil Biol Biochem 42:1653-1656. https://doi. org/10.1016/j.soilbio.2010.05.026

Subke JA, Inglima I, Cotrufo MF (2006) Trends and methodological impacts in soil $\mathrm{CO}_{2}$ efflux partitioning: a metaanalytical review. Glob Chang Biol 12:921-943. https://doi. org/10.1111/j.1365-2486.2006.01117.x

Sulman BN, Moore JAM, Abramoff R, Averill C, Kivlin S, Georgiou K, Sridhar B, Hartman MD, Wang G, Wieder WR, Bradford MA, Luo Y, Mayes MA, Morrison E, Riley WJ, Salazar A, Schimel JP, Tang J, Classen AT (2018) Multiple models and experiments underscore large uncertainty in soil carbon dynamics. Biogeochemistry 141 : 109-123. https://doi.org/10.1007/s10533-018-0509-z

Talbot JM, Allison SD, Treseder KK (2008) Decomposers in disguise: Mycorrhizal fungi as regulators of soil $\mathrm{C}$ dynamics in ecosystems under global change. Funct Ecol 22:955-963. https://doi.org/10.1111/j.1365-2435.2008.01402.x

Tenow O, Bylund H (2000) Recovery of a Betula pubescens Forest in northern Sweden after severe defoliation by Epirrita autumnata. J Veg Sci 11:855-862. https://doi. org/10.2307/3236555

Tømmervik H, Johansen B, Riseth JÅ et al (2009) Above ground biomass changes in the mountain birch forests and mountain heaths of Finnmarksvidda, northern Norway, in the period 1957-2006. For Ecol Manag 257:244-257. https://doi. org/10.1016/j.foreco.2008.08.038

Van Bogaert R, Haneca K, Hoogesteger J et al (2011) A century of tree line changes in sub-Arctic Sweden shows local and regional variability and only a minor influence of $20^{\text {th }}$ century climate warming. J Biogeogr 38:907-921. https://doi. org/10.1111/j.1365-2699.2010.02453.x

Varik M, Aosaar J, Ostonen I, et al (2013) Carbon and nitrogen accumulation in belowground tree biomass in a chronosequence of silver birch stands. Forest Ecology and Management 302:62-70. https://doi.org/10.1016/j. foreco.2013.03.033

Wallander H, Nilsson LO, Hagerberg D, Bååth E (2001) Estimation of the biomass and seasonal growth of external mycelium of ectomycorrhizal fungi in the field. New Phytol 151:753-760. https://doi.org/10.1046/j.0028-646 x.2001.00199.x

Wardle DA, Bardgett RD, Klironomos JN et al (2004) Ecological linkages between aboveground and belowground biota. Science 304:1629-1633. https://doi.org/10.1126 /science.1094875

Weigt RB, Raidl S, Verma R, Agerer R (2012) Exploration typespecific standard values of extramatrical mycelium - a step towards quantifying ectomycorrhizal space occupation and biomass in natural soil. Mycol Prog 11:287-297. https://doi. org/10.1007/s11557-011-0750-5

White TJ, Bruns S, Lee S, Taylor J (1990) Amplification and direct sequencing of fungal ribosomal RNA genes for phylogenetics. PCR Protocols: A Guide to Methods and Applications 315-322

Wiemken V, Boller T (2002) Ectomycorrhiza: gene expression, metabolism and the wood-wide web. Curr Opin Plant Biol 5: 355-361. https://doi.org/10.1016/S1369-5266(02)00269-8

Wild B, Gentsch N, Čapek P, Diáková K, Alves RJE, Bárta J, Gittel A, Hugelius G, Knoltsch A, Kuhry P, Lashchinskiy N, Mikutta R, Palmtag J, Schleper C, Schnecker J, Shibistova O, Takriti M, Torsvik VL, Urich T, Watzka M, Šantrůčková H, Guggenberger G, Richter A (2016) Plant-derived compounds stimulate the decomposition of organic matter in arctic permafrost soils. Sci Rep 6:25607-25611. https://doi. org/10.1038/srep25607

Wookey PA, Aerts R, Bardgett RD et al (2009) Ecosystem feedbacks and cascade processes: understanding their role in the responses of Arctic and alpine ecosystems to environmental change. Glob Chang Biol 15:1153-1172. https://doi. org/10.1111/j.1365-2486.2008.01801.x 
Wurzburger N, Clemmensen KE (2018) From mycorrhizal fungal traits to ecosystem properties - and back again. J Ecol 106: 463-467. https://doi.org/10.1111/1365-2745.12922

Zhang W, Parker KM, Luo Y et al (2005) Soil microbial responses to experimental warming and clipping in a tallgrass prairie. Glob Chang Biol 11:266-277. https://doi.org/10.1111 j.1365-2486.2005.00902.x
Publisher's note Springer Nature remains neutral with regard to jurisdictional claims in published maps and institutional affiliations. 